\title{
Simulation and comparison of silvicultural alternatives for even-aged Pinus pinaster Ait stands in Galicia (Northwestern Spain)
}

\author{
Roque Rodríguez Soalleiro ${ }^{\mathrm{a}, *}$, Juan Gabriel Álvarez Gonzalez ${ }^{\mathrm{a}}$ and Jörg Schröder ${ }^{\mathrm{b}}$ \\ ${ }^{a}$ Escuela Politécnica Superior de Lugo, Universidad de Santiago de Compostela, Campus Universitario S/N, 27002 Lugo, Spain \\ ${ }^{\mathrm{b}}$ Georg-August-Universität Göttingen, Institut für Forsteinrichtung und Ertragskunde, Büsgenweg 5, 37077 Göttingen, Germany
}

(Received 30 November 1999; accepted 19 April 2000)

\begin{abstract}
Three silvicultural alternatives for pure, even-aged stands of maritime pine (Pinus pinaster Ait) grown in Galicia (Northwestern Spain) are simulated and compared. First, each silvicultural alternative is described by a specific combination of initial stand-density, pre-commercial treatment, thinning pattern, and rotation age. The development of each silvicultural alternative is simulated using a regional growth and yield projection system based on a dynamic stand growth simulator and a size class model for representative trees. Different timber grades associated with each alternative are predicted and estimates of costs and selling prices are used to predict a cash flow pattern for each of the simulated alternatives. Finally, the alternatives are ranked using the criteria net present value of an infinite series of like rotations and internal rate of return. For the present market conditions, the most intensive silvicultural alternative is the most desirable one if profit maximization is the objective of forest management.
\end{abstract}

Pinus pinaster Ait / silviculture / Galicia / growth and yield modelling

Résumé - Simulation et comparaison de régimes sylvicoles pour des forêts régulières de Pinus pinaster Ait. en Galicie (NordOuest de l'Espagne). Trois alternatives de sylviculture pour peuplements purs et réguliers de pin maritime (Pinus pinaster Ait) en Galicie (NO de l'Espagne) sont simulées et comparées. Chaque alternative est formulée comme une combinaison spécifique de densité initiale, dépressages, régime d'éclaircies et durée de la révolution. Le développement du peuplement à chaque alternative est simulé avec un modèle régional de projection de la croissance et production, basé sur un des modèles dynamiques de croissance en surface terrière et sur des modèles de distribution des classes de diamètres. Pour chaque alternative on a obtenu la production totale de bois par catégories de dimension, les coûts de gestion, les prix de vente et un bilan économique complet. Les alternatives sont classées en employant le bénéfice actualisé sur une infinité de révolutions identiques et le taux interne de rentabilité. Dans les conditions actuelles, l'alternative la plus intensive est intéressante si l'objectif de l'aménagement forestier est la maximalisation du revenu économique direct.

Pinus pinaster Ait / sylviculture / Galicie / modèle de croissance

\section{INTRODUCTION}

By describing the medium and long-term development of a forest stand, silvicultural planning ensures continuity of forest management. For even-aged commercial stands of maritime pine (Pinus pinaster Ait) in Galicia, this important task was achieved until the later sixties by using the classical yield tables developed

* Correspondence and reprints

Tel. (34) 982252 303; Fax. (34) 982241 835; e-mail: roquers@lugo.usc.es 
by Echeverría and De Pedro [6]. In combination with a limited number of prescribed thinning types, the tables produce standard descriptions of future management activities in order to maximize the volume production for the pulpwood industry. The initial densities prescribed in the tables were up to 5000 stems per hectare, thinnings were of moderate intensity and standard from below, and the rotation length was determined as a function of the culmination of the mean-annual volume increment (between 25 and 30 years depending on site productivity).

The practical utility of this simple planning tool was declining since more intensive silvicultural concepts were introduced in Northwestern Spain as a result of increasing harvesting costs and stagnating pulpwood prices. Nowadays, maritime pine stands in Galicia are grown for a product mix dominated by timber for regional sawlog production. The corresponding silvicultural concepts are characterised by reduced initial densities, selective mixed thinnings, emphasis on pruning, and longer rotations up to 35 years. Sometimes, even intensive soil preparation and fertilization techniques are applied and the use of genetically improved stock is beginning to emerge. The increased management intensity has also increased the complexity of decision-making and forest managers need new management guidelines, which can provide direction for practical planning purposes. A simple approach to draft an idealistic silvicultural concept is to specify a set of silvicultural alternatives, simulate the development of each alternative using a flexible growth-projection system, and select the best alternative using specified decision criteria [4].

In the present paper, we focus exclusively on three silvicultural alternatives, which represent the range of graduated management intensities applied at present in Galicia. First, each alternative is roughly outlined beginning with stand regeneration and ending with the final harvest of the mature trees. In a second step, the silvicultural alternatives are simulated using a growth projection system based on previous studies [1, 16, 23]. The main purpose of the paper is to analyze the differences in growth and yield generated for each alternative and to find out, which alternative is the most desired if profit maximization is the objective.

\section{SILVICULTURAL ALTERNATIVES}

Alternative (1) is characterised by maintaining a high density during the entire rotation to produce a high quantity of timber volume. The rotation is 30 years and the initial planting density corresponds to a planting schedule of $2 \times 2$ meters ( 2500 stems per hectare). The first thinning is systematic and early. It should be realised between ages of 10-12 years by site productivity. Afterwards, three more thinnings will be done. All thinnings are standard from below and of moderate weight (Removal of 20 to $25 \%$ of the stem number before thinning). Pruning is realised to a height of 2.5 meters and the Hart-index ${ }^{1}$ for advanced ages is between 0.16 and 0.17 .

Alternative (2) is generally characterised by lower densities. Loss in volume production as a result of lower stand densities is accepted to obtain higher individual tree dimensions. The basic product objective is quality sawn timber and only a small percentage of timber is destined to the fibre board industry. Although alternative (2) maintains a conservative tendency, it is the most common silvicultural concept applied today in Galicia. The rotation is 35 years and the initial stand density is 1670 stems per hectare corresponding to a planting scheme of $3 \times 2$ meters. All together three thinnings are planed. The thinnings are selective and the thinning weights are relatively high (removing 25 to 30 percent of stems before thinning). The trees, which are expected to reach rotation age are low and high pruned to a height of 5.5 meters. The value of the Hart-index for advanced ages is 0.22 .

Alternative (3) is one of the most intensive silvicultural alternatives applied today in Galicia. ${ }^{2}$ It should always be associated to the application of genetically superior stock as the number of trees for selective thinnings is considerably reduced. The initial density is 1100 stems per hectare $(3 \times 3 \mathrm{~m})$ and the rotation is 35 years. All together, only two thinning are carried out. Both thinning regimes are selective and the thinning weights are rather high (33 to $40 \%$ ). The first thinning is realised between a stand age of 16 and 18 years thus increasing the possibility to obtain logs of considerable size to provide an early financial return. All trees, which are expected to reach rotation age, are low and high pruned to a height of $5.5 \mathrm{~m}$. The Hart-index for advanced ages is 0.24 .

\footnotetext{
1 The Hart-index or relative spacing index is a stand density measure, which is expressed by the ratio of the average distance between the trees growing in a stand $(\mathrm{m})$ and the dominant stand-height (m). Commonly, the index has been used to control density in intensively managed plantations $[15,16]$.

2 Plantations with even lower densities are commonly associated in Galicia to commercial grazing. This concept is, without doubt, a very interesting alternative. However, it was not considered in the present paper because the stand-growth simulator applied does not provide reliable predictions under such extreme conditions.
} 


\section{METHODS}

\subsection{Growth simulation}

The growth and yield prediction system used to simulate the development of the three silvicultural alternatives is based on a stand growth simulator developed by Rodríguez [23] and the corresponding software application "PINASTER" implemented by Álvarez et al. [2]. The state variables of the stand considered in the model were basal area, dominant height and density. Stand density evolution is open to diverse silvicultural regimes depending to thinning application. No natural mortality function was considered, since very dense permanent plots didn't show any density reduction. Dominant height evolution is obtained by using site index curves for the coastal area of Galicia, with a remarkable different guide than those for the inland area [22].

One of the most important single elements of this stand growth-simulator is a dynamic basal area increment function. Based on the state space approach proposed by García [11, 12], it is assumed that the basal area increment for a stand can be determined independently from the specific treatment history using initial basal area and age as explanatory variables [10]. Thus, the simulator allows the evaluation of a relatively wide range of silvicultural alternatives.

In the present paper, each of the three silvicultural alternatives outlined above was simulated considering two different site qualities defined by the site index at a reference age of 20 years $\left(\mathrm{SI}_{20}\right)$. The relatively better site productivity was $S I_{20}=16$ meters and the relatively poorer one $S I_{20}=13$ meters, both corresponding to the geographical area "coastal area of Galicia" [22]. The diameter distributions of representative trees, which were used in this study as an indispensable pre-requisite to estimate single tree dimensions and product yields, are predicted by means of the two-parameter Weibull function:

$$
\mathrm{F}\left(d_{i}\right)=1-e^{-\left(\frac{d_{i}}{\beta}\right)^{\gamma}}
$$

where $\mathrm{F}(d)$ is the probability-density-function for the breast height diameter of the representative tree $i(\mathrm{~cm})$ and $\beta$ and $\gamma$ are the Weibull parameters, which are estimated as a function of the quadratic mean diameter $D_{\mathrm{g}}$ and the mean diameter $D_{\mathrm{m}}$. The value of $D_{\mathrm{g}}$ derives directly from the stand state variables. To recover the value of $D_{\mathrm{m}}$ a simple linear regression from $D_{\mathrm{g}}$ is used [1]:

$$
\beta=-4.78+1.058 D_{\mathrm{g}}
$$

$$
\gamma=2.203-\frac{0.0628}{\ln \left(D_{\mathrm{m}} / D_{\mathrm{g}}\right)}
$$

Based on the generated diameter distributions, the heights of the representative trees were estimated using the following generalised diameter height relationship developed by Schröder and Álvarez [25]:

$h_{i}=1.3+\left(5.172+1.386 H_{0}-0.137 D_{\mathrm{g}}+0.027 G\right) e^{\frac{-2.99}{\sqrt{d_{i}}}}$

where the variables dominant stand height $H_{0}(\mathrm{~m})$, quadratic mean diameter $D_{\mathrm{g}}(\mathrm{cm})$, and basal area $G\left(\mathrm{~m}^{2} \mathrm{ha}^{-1}\right)$ are derived using the PINASTER programme.

Product yields were finally derived as a function of the generated diameter and height distributions using the generalised taper curves presented for maritime pine stands by Ruíz Dana [24]. Considering 2.5 meter logs, the following timber grades were specified as a function of the thin-end diameter of each log:

Grade I: Logs with a thin-end diameter smaller than $22 \mathrm{~cm}$. The destination of this product is basically the fibre board production.

Grade IIa: Branch-less logs with a thin-end diameter between 22 and $35 \mathrm{~cm}$ for producing high quality sawn timber.

Grade IIb: Logs with a thin-end diameter of 22 and $35 \mathrm{~cm}$ containing dead branches to produce sawn timber.

Grade III: Branch-less and error-free logs with a thinend diameter larger than $35 \mathrm{~cm}$ for the production of veneer.

\subsection{Economic evaluation}

The criterion net present value of an infinite series (NPVIS) of like rotations [19] was used to determine for each silvicultural alternative, how much is the predicted promise of future income worth today. The NPVIS associated with a given cash flow sequence can be calculated, in a continuous-time formulation, as

$$
N P V I S=\sum_{t=0}^{\infty} C_{t}\left(e^{-i t}\right)
$$

where $C_{t}=$ net cash flow in period $t$ and $i=$ discount rate $[4,19]$. The basic discount rate considered in the present paper for calculating the NPVIS-values was 0.04 (4\%). Discount rates of 0.03 and 0.05 were also used in order to analyse the effect of altering discount rates on the economic results. We also used the criterion internal rate 
Table I. Generated stand development for $S I_{20}=16 \mathrm{~m}$.

\begin{tabular}{|c|c|c|c|c|c|c|c|c|c|c|c|c|c|}
\hline \multirow{3}{*}{$\begin{array}{l}\text { Age } \\
\text { years }\end{array}$} & \multicolumn{5}{|c|}{ Main Crop before thinning } & \multicolumn{4}{|c|}{ Yield from thinnings } & \multicolumn{3}{|c|}{ Main crop after thinning } & \multirow{2}{*}{$\begin{array}{c}\text { Increment } \\
M A I \\
\mathrm{~m}^{3} \mathrm{ha}^{-1}\end{array}$} \\
\hline & $\begin{array}{c}H_{0} \\
\mathrm{~m}\end{array}$ & $\begin{array}{c}N \\
\text { stems ha }^{-1}\end{array}$ & $\begin{array}{l}D_{\mathrm{g}} \\
\mathrm{cm}\end{array}$ & $\begin{array}{c}G \\
\mathrm{~m}^{2} \mathrm{ha}^{-1}\end{array}$ & $\begin{array}{c}V \\
\mathrm{~m}^{3} \mathrm{ha}^{-1}\end{array}$ & $\begin{array}{c}N \\
\text { stems ha }^{-1}\end{array}$ & $\begin{array}{c}G \\
\mathrm{~m}^{2} \mathrm{ha}^{-1}\end{array}$ & $\begin{array}{c}V \\
\mathrm{~m}^{3} \mathrm{ha}^{-1}\end{array}$ & $\begin{array}{c}V_{\text {ea }} \\
\mathrm{m}^{3} \mathrm{ha}^{-1}\end{array}$ & $\begin{array}{c}N \\
\text { stems } \text { ha }^{-1}\end{array}$ & $\begin{array}{c}G \\
\mathrm{~m}^{2} \mathrm{ha}^{-1}\end{array}$ & $\begin{array}{c}V \\
\mathrm{~m}^{3} \mathrm{ha}^{-1}\end{array}$ & \\
\hline & \multicolumn{13}{|c|}{ ALTERNATIVE 1} \\
\hline 5 & 3.8 & 2500 & 5.6 & 6.3 & 10.1 & 0 & 0.0 & 0.0 & 0.0 & 2500 & 6.3 & 10.1 & 2.0 \\
\hline 10 & 8.4 & 2500 & 9.7 & 18.5 & 65.9 & 800 & 2.4 & 8.4 & 8.4 & 1700 & 16.2 & 57.4 & 6.6 \\
\hline 15 & 12.6 & 1700 & 15.1 & 30.4 & 160.8 & 450 & 3.2 & 17.0 & 25.5 & 1250 & 27.2 & 143.8 & 11.3 \\
\hline 20 & 16.0 & 1250 & 19.5 & 37.1 & 250.6 & 250 & 3.0 & 20.0 & 45.5 & 1000 & 34.2 & 230.5 & 13.8 \\
\hline 25 & 18.8 & 1000 & 23.0 & 41.7 & 329.5 & 200 & 3.3 & 26.4 & 71.9 & 800 & 38.3 & 303.2 & 15.0 \\
\hline 30 & 20.9 & 800 & 26.5 & 44.2 & 390.1 & 0 & 0.0 & 0.0 & 71.9 & 800 & 44.2 & 390.1 & 15.4 \\
\hline \multicolumn{14}{|c|}{ ALTERNATIVE 2} \\
\hline 5 & 3.8 & 1670 & 7.1 & 6.7 & 10.7 & 0 & 0.0 & 0.0 & 0.0 & 1670 & 6.7 & 10.7 & 2.1 \\
\hline 10 & 8.4 & 1670 & 11.2 & 16.4 & 58.5 & 0 & 0.0 & 0.0 & 0.0 & 1670 & 16.4 & 58.4 & 5.8 \\
\hline 13 & 11.0 & 1670 & 14.0 & 25.6 & 118.5 & 520 & 4.8 & 22.1 & 22.1 & 1150 & 20.8 & 96.4 & 9.1 \\
\hline 18 & 14.7 & 1150 & 18.8 & 31.8 & 197.4 & 320 & 5.3 & 32.9 & 55.1 & 830 & 26.5 & 164.4 & 12.2 \\
\hline 23 & 17.7 & 830 & 23.0 & 34.4 & 27.2 & 250 & 6.2 & 46.5 & 101.6 & 580 & 28.2 & 210.7 & 13.6 \\
\hline 30 & 20.9 & 580 & 28.2 & 36.1 & 319.1 & 0 & 0.0 & 0.0 & 101.6 & 580 & 36.1 & 319.1 & 14.0 \\
\hline 35 & 22.6 & 580 & 29.9 & 40.7 & 388.4 & 0 & 0.0 & 0.0 & 101.6 & 580 & 40.7 & 388.4 & 14.0 \\
\hline \multicolumn{14}{|c|}{ ALTERNATIVE 3} \\
\hline 5 & 3.8 & 1100 & 9.2 & 7.3 & 11.8 & 0 & 0.0 & 0.0 & 0.0 & 1100 & 7.3 & 11.8 & 2.4 \\
\hline 10 & 8.4 & 1100 & 13.3 & 15.3 & 54.2 & 0 & 0.0 & 0.0 & 0.0 & 1100 & 15.3 & 54.2 & 5.4 \\
\hline 16 & 13.3 & 1100 & 19.1 & 31.5 & 176.8 & 400 & 9.2 & 51.4 & 51.4 & 700 & 22.4 & 125.4 & 11.0 \\
\hline 22 & 17.2 & 700 & 24.3 & 32.5 & 235.6 & 300 & 11.2 & 80.8 & 132.2 & 400 & 21.4 & 154.8 & 13.0 \\
\hline 25 & 18.8 & 400 & 28.2 & 24.9 & 197.2 & 0 & 0.0 & 0.0 & 132.2 & 400 & 24.9 & 197.2 & 13.2 \\
\hline 30 & 20.9 & 400 & 30.9 & 30.0 & 265.1 & 0 & 0.0 & 0.0 & 132.2 & 400 & 30.0 & 265.1 & 13.2 \\
\hline 35 & 22.6 & 400 & 33.1 & 34.3 & 327.6 & 0 & 0.0 & 0.0 & 132.2 & 400 & 34.3 & 327.6 & 13.1 \\
\hline
\end{tabular}

Table II. Generated stand development for $S I_{20}=13 \mathrm{~m}$.

\begin{tabular}{|c|c|c|c|c|c|c|c|c|c|c|c|c|c|}
\hline \multirow{3}{*}{$\begin{array}{l}\text { Age } \\
\text { years }\end{array}$} & \multicolumn{5}{|c|}{ Main Crop before thinning } & \multicolumn{4}{|c|}{ Yield from thinnings } & \multicolumn{3}{|c|}{ Main crop after thinning } & \multirow{2}{*}{$\begin{array}{c}\text { Increment } \\
M A I \\
\mathrm{~m}^{3} \mathrm{ha}^{-1}\end{array}$} \\
\hline & $\begin{array}{c}H_{0} \\
\mathrm{~m}\end{array}$ & $\begin{array}{c}N \\
\text { stems ha } \\
\text { he }\end{array}$ & $\begin{array}{l}D_{\mathrm{g}} \\
\mathrm{cm}\end{array}$ & $\begin{array}{c}G \\
\mathrm{~m}^{2} \mathrm{ha}^{-1}\end{array}$ & $\begin{array}{c}V \\
\mathrm{~m}^{3} \mathrm{ha}^{-1}\end{array}$ & $\begin{array}{c}N \\
\text { stems ha }^{-1}\end{array}$ & $\begin{array}{c}G \\
\mathrm{~m}^{2} \mathrm{ha}^{-1}\end{array}$ & $\begin{array}{c}V \\
\mathrm{~m}^{3} \mathrm{ha}^{-1}\end{array}$ & $\begin{array}{c}V_{\mathrm{ea}} \\
\mathrm{m}^{3} \mathrm{ha}^{-1}\end{array}$ & $\begin{array}{c}N \\
\text { stems ha }^{-1}\end{array}$ & $\begin{array}{c}G \\
\mathrm{~m}^{2} \mathrm{ha}^{-1}\end{array}$ & $\begin{array}{c}V \\
\mathrm{~m}^{3} \mathrm{ha}^{-1}\end{array}$ & \\
\hline & \multicolumn{13}{|c|}{ ALTERNATIVE 1} \\
\hline 5 & 3.1 & 2500 & 5.0 & 4.9 & 6.4 & 0 & 0.0 & 0.0 & 0.0 & 2500 & 4.9 & 6.4 & 1.3 \\
\hline 12 & 8.3 & 2500 & 10.0 & 19.5 & 68.0 & 700 & 2.2 & 7.6 & 7.6 & 1800 & 17.3 & 60.4 & 5.7 \\
\hline 17 & 11.4 & 1800 & 14.3 & 28.9 & 138.8 & 400 & 2.6 & 12.3 & 19.9 & 1400 & 26.3 & 126.4 & 8.6 \\
\hline 22 & 14.0 & 1400 & 17.8 & 34.8 & 204.7 & 200 & 2.0 & 11.7 & 31.6 & 1200 & 32.8 & 193.0 & 10.2 \\
\hline 27 & 16.0 & 1200 & 20.4 & 39.3 & 265.5 & 200 & 2.6 & 17.7 & 49.3 & 1000 & 36.7 & 247.8 & 11.0 \\
\hline 30 & 17.0 & 1000 & 22.6 & 40.0 & 286.8 & 0 & 0.0 & 0.0 & 49.3 & 1000 & 40.0 & 286.8 & 11.2 \\
\hline \multicolumn{14}{|c|}{ ALTERNATIVE 2} \\
\hline 5 & 3.1 & 1670 & 6.5 & 5.5 & 7.2 & 0 & 0.0 & 0.0 & 0.0 & 1670 & 5.5 & 7.2 & 1.4 \\
\hline 10 & 6.8 & 1670 & 9.8 & 12.6 & 36.4 & 0 & 0.0 & 0.0 & 0.0 & 1670 & 12.6 & 36.4 & 3.6 \\
\hline 15 & 10.2 & 1670 & 14.1 & 25.9 & 111.3 & 470 & 4.4 & 18.8 & 18.8 & 1200 & 21.5 & 92.5 & 7.4 \\
\hline 20 & 11.9 & 1200 & 18.1 & 30.8 & 168.8 & 300 & 4.6 & 25.3 & 44.1 & 900 & 26.2 & 143.5 & 9.4 \\
\hline 25 & 14.8 & 900 & 21.6 & 33.1 & 212.5 & 200 & 4.4 & 28.3 & 72.5 & 700 & 28.7 & 184.2 & 10.3 \\
\hline 30 & 17.0 & 700 & 24.9 & 34.0 & 243.8 & 0 & 0.0 & 0.0 & 72.5 & 700 & 34.0 & 243.8 & 10.5 \\
\hline 35 & 18.4 & 700 & 26.4 & 38.4 & 298.2 & 0 & 0.0 & 0.0 & 72.5 & 700 & 38.4 & 298.2 & 10.6 \\
\hline \multicolumn{14}{|c|}{ ALTERNATIVE 3} \\
\hline 5 & 3.1 & 1100 & 8.6 & 6.4 & 8.3 & 0 & 0.0 & 0.0 & 0.0 & 1100 & 6.4 & 8.3 & 1.7 \\
\hline 10 & 6.8 & 1100 & 11.9 & 12.2 & 35.3 & 0 & 0.0 & 0.0 & 0.0 & 1100 & 12.2 & 35.3 & 3.5 \\
\hline 15 & 10.2 & 1100 & 17.1 & 25.4 & 109.2 & 0 & 0.0 & 0.0 & 0.0 & 1100 & 25.4 & 109.2 & 7.3 \\
\hline 18 & 11.9 & 1100 & 19.1 & 31.6 & 159.0 & 350 & 8.0 & 40.5 & 40.5 & 750 & 23.5 & 118.5 & 8.8 \\
\hline 24 & 14.8 & 750 & 23.5 & 32.4 & 203.0 & 250 & 8.6 & 54.1 & 94.6 & 500 & 23.8 & 148.8 & 10.1 \\
\hline 30 & 17.0 & 500 & 27.7 & 30.0 & 215.5 & 0 & 0.0 & 0.0 & 94.6 & 500 & 30.0 & 215.5 & 10.3 \\
\hline 35 & 18.4 & 500 & 29.6 & 34.3 & 266.2 & 0 & 0.0 & 0.0 & 94.6 & 500 & 34.3 & 266.2 & 10.3 \\
\hline
\end{tabular}


of return (IRR), which is defined as that discount rate, which makes the NPVIS-value of a silvicultural strategy equal to zero.

In order to calculate the required cash flows, stumpage prices per $\mathrm{m}^{3}$ were estimated for each of the above defined timber grades in accordance to the results of timber auctions realised by the forest administration of Galicia in the previous three years (Grade I $=18 €$, Grade IIa $=60 €$, Grade IIb $=36 €$, Grade III $=90 €$ ). Furthermore, it was assumed that the removal of logs with a mid-length diameter inferior to $10 \mathrm{~cm}$ would provide a null financial benefit. The regeneration costs per hectare were assumed $1500 €$ for alternative (1), $1320 €$ for alternative (2), and $1200 €$ for alternative (3). The pruning costs were calculated respectively for each specified pruning schedule. For simplicity, the per hectare bare land value was not considered for the analysis and the annual management costs were generally assumed $15 €$ per hectare.

All calculations were carried out for two cases, plantation and natural regeneration. In the case of natural regeneration, the regeneration costs were reduced to the expenditure corresponding to an early systematic thinning to reduce the initial densities to those ones considered for plantation. Additionally, a sensitivity analysis was carried out for all calculations altering the prices for the timber grades IIa, IIb, and III by $\pm 20 \%$.

\section{RESULTS}

\subsection{Stand development and product yields}

The PINASTER programme was used to generate two yield tables for each silvicultural alternative, one for $S I_{20}=16 \mathrm{~m}$ (table $I$ ) and another one for $S I_{20}=13 \mathrm{~m}$ (table II); $N=$ number of stems per hectare, $\mathrm{V}=$ stand volume $\left(\mathrm{m}^{3} \mathrm{ha}^{-1}\right), V_{\text {ea }}=$ the accumulated volume removed by thinnings $\left(\mathrm{m}^{3} \mathrm{ha}^{-1}\right)$, and $M A I=$ mean annual increment $\left(\mathrm{m}^{3} \mathrm{ha}^{-1}\right)$.

In the case of $S I_{20}=16 \mathrm{~m}$, the first alternative shows $10 \%$ more total volume production than the second alternative and $17 \%$ more than the third alternative. These percentages are reduced respectively to $5.8 \%$ and $8.6 \%$ if the poorer site productivity is considered (table II). For the better site productivity, the volume of the mean tree at clear cutting is $0.49,0.67$, and $0.82 \mathrm{~m}^{3}$ for alternative (1), (2), and (3) respectively. For the inferior site productivity, values of $0.29,0.43$, and $0.53 \mathrm{~m}^{3}$ are obtained. In the case of the better site productivity, the percentages of total volume production removed by successive thinnings $\left(V_{\text {ea }}\right)$ are $15.5,20.7$, and $28.7 \mathrm{~m}^{3}$ for the alternatives (1), (2), and (3). For the inferior site productivity these values are $14.7,19.5$, and $26.2 \mathrm{~m}^{3}$ indicating the increasing management intensity from alternative (1) over alternative (2) to alternative (3).

The diameter distributions obtained for each alternative at clear cutting are presented in table III. It is shown that the proportional accumulation of stems in the lower diameter classes is highest for alternative (1) and lowest for alternative (3). The number of stems in the lower diameter classes is generally higher in the case of the inferior site productivity. Table IV shows the proportional share of the four specified timber grades on the total yield harvested at clear cutting. The highest values of the timber grades IIa, IIb and III are obtained for the third alternative (61 to $69 \%$ all together after site productivity) whereas the first alternative produces basically industrial wood (between 55 and $77 \%$ depending on site productivity). An intermediate result is obtained for the second alternative. Table $V$ lists the quadratic mean diameter of the trees removed in successive thinnings. It is shown that the third alternative provides generally superior individual stem dimensions.

\subsection{Economic evaluation}

The results of the economic evaluation are presented in table VI. Independently from site index, the third alternative provides generally higher NPVIS-values and is, therefore, superior to both, the first and the second alternative. The second alternative provides intermediate results. This ranking remains generally constant even if different discount rates $i$ and different prices $p$ for the timber grades IIa, IIb, and III are assumed (cf. table VI). However, the differences between the NPVIS-values decline if $i$ is increasing or if $p$ is decreasing, following similar tendencies as those pointed by Calvet et al. [3].

Taking natural regeneration as a starting point, generally better economic results are obtained resulting in increased IRR-values for all three alternatives. This shows the economical relevance of taking advantage of the high potential of maritime pine for natural regeneration. For the poorer site quality, the NPVIS-values are generally reduced for all three alternatives. In the case of the first alternative, the value is even negative if discount rates of $4 \%$ or higher are considered, meaning that, in this case, the returns from the investment will not be sufficient to repay the capital invested.

\section{DISCUSSION AND CONCLUSIONS}

Usually, the objective of profit oriented forest managers is to obtain a present value and an internal rate 
Table III. Diameter distributions obtained at clear cutting (5 $\mathrm{cm}$ diameter-classes).

\begin{tabular}{|c|c|c|c|c|c|c|}
\hline $\begin{array}{l}\text { Size class } \\
\mathrm{cm}\end{array}$ & Alt. 1 & $\begin{array}{c}S I_{20}=16 \mathrm{~m} \\
\text { Alt. } 2\end{array}$ & Alt. 3 & Alt. 1 & $\begin{array}{c}S I_{20}=13 \mathrm{~m} \\
\text { Alt. } 2\end{array}$ & Alt. 3 \\
\hline $10-15$ & 121 & 56 & 26 & 262 & 107 & 51 \\
\hline $15-20$ & 162 & 85 & 43 & 281 & 143 & 76 \\
\hline $20-25$ & 194 & 117 & 65 & 253 & 170 & 103 \\
\hline $25-30$ & 165 & 123 & 77 & 143 & 144 & 106 \\
\hline $30-35$ & 101 & 99 & 74 & 50 & 87 & 83 \\
\hline $35-40$ & 43 & 60 & 56 & 10 & 36 & 49 \\
\hline $40-45$ & 12 & 27 & 34 & 1 & 10 & 21 \\
\hline $45-50$ & 2 & 9 & 16 & 0 & 3 & 7 \\
\hline $50-55$ & 0 & 4 & 9 & 0 & 0 & 4 \\
\hline Total & 800 & 580 & 400 & 1000 & 700 & 500 \\
\hline
\end{tabular}

Table IV. Proportional share of different timber grades on the total harvest at clear cutting.

\begin{tabular}{|c|c|c|c|c|}
\hline $\begin{array}{l}\text { Alternative and } \\
\text { site productivity }\end{array}$ & $\underset{\%}{\text { Grade I }}$ & $\underset{\%}{\text { Grade IIa }}$ & $\begin{array}{c}\text { Grade IIb } \\
\%\end{array}$ & $\begin{array}{c}\text { Grade III } \\
\%\end{array}$ \\
\hline Alt. $1\left(S I_{20}=16 \mathrm{~m}\right)$ & 55 & 32 & 11 & 2 \\
\hline Alt. $2\left(S I_{20}=16 \mathrm{~m}\right)$ & 41 & 33 & 18 & 8 \\
\hline Alt. $3\left(S I_{20}=16 \mathrm{~m}\right)$ & 31 & 30 & 23 & 16 \\
\hline Alt. $1\left(S I_{20}=13 \mathrm{~m}\right)$ & 77 & 19 & 4 & 0 \\
\hline Alt. $2\left(S I_{20}=13 \mathrm{~m}\right)$ & 52 & 37 & 9 & 2 \\
\hline Alt. $3\left(S I_{20}=13 \mathrm{~m}\right)$ & 39 & 38 & 15 & 8 \\
\hline
\end{tabular}

Table V. Quadratic mean diameters of the trees removed by successive thinnings.

\begin{tabular}{lcccc}
\hline $\begin{array}{l}\text { Alternative and } \\
\text { site productivity }\end{array}$ & 1st thinning & $\begin{array}{c}\text { Quadratic mean diameter of the removed trees }(\mathrm{cm}) \\
\text { 2nd thinning }\end{array}$ & 3rd thinning & 4th thinning \\
\hline Alt. $1\left(S I_{20}=16 \mathrm{~m}\right)$ & 6.2 & 9.5 & 12.3 & 14.5 \\
Alt. $\left(S I_{20}=16 \mathrm{~m}\right)$ & 10.8 & 14.5 & - & - \\
Alt. $3\left(S_{20}=16 \mathrm{~m}\right)$ & 17.1 & 21.7 & 11.2 & 12.9 \\
Alt. $1\left(S I_{20}=13 \mathrm{~m}\right)$ & 6.3 & 9.0 & 16.7 & - \\
Alt. $2\left(S I_{20}=13 \mathrm{~m}\right)$ & 10.9 & 13.9 & - & - \\
Alt. 3 $\left(S I_{20}=13 \mathrm{~m}\right)$ & 17.0 & 20.9 & & - \\
\hline
\end{tabular}

of return as high as possible. Considering the results obtained for the three silvicultural alternatives simulated in the present paper, the third alternative is clearly favoured for the applied criteria. In the first place, the superiority of the third alternative is a result of a relative high production of high-value timber products (cf. table $V$ ). The relatively low total volume-production (tables I and II) is, on the other hand, economically not a disadvantage indicating that the current market conditions are generally favouring silvicultural concepts, which are characterised by low densities and intensive pre-commercial treatments.
From a theoretical point of view, it would be a revealing task to optimise the growth prediction system applied in the present paper using numerical algorithms $[17,18$, $20,27]$. Although a realistic treatment schedule would result from the optimization procedure, the practical usefulness of such a single stand result would be rather limited in practical silvicultural planning. The reason is that for a specified cutting period, timber-yields and cash flows must commonly be stabilised or smoothed over time meaning that the optimum single-stand strategy is not necessarily the best approach to adopt on all stands of a forest property. 
Table VI. Results of the economic analysis; NPVIS = net present value of an infinite series of like rotations $\left(€\right.$ ha $\left.^{-1}\right) ; i=$ discount rate; $p=$ stumpage price for timber grades IIa, IIb, III; IRR = internal rate of return.

\begin{tabular}{|c|c|c|c|c|c|c|}
\hline \multirow[t]{2}{*}{$\begin{array}{l}\text { Alternative and } \\
\text { site productivity }\end{array}$} & \multirow{2}{*}{$\begin{array}{l}i=0.03 \\
p \pm 0 \%\end{array}$} & \multicolumn{3}{|c|}{$\begin{array}{c}N P V \\
i=0.04\end{array}$} & \multirow{2}{*}{$\begin{array}{l}i=0.05 \\
p \pm 0 \%\end{array}$} & \multirow[t]{2}{*}{ IRR } \\
\hline & & $p-20 \%$ & $p \pm 0 \%$ & $p+20 \%$ & & \\
\hline $\begin{array}{l}\text { Plantation: } \\
\text { Alt. } 1\left(S I_{20}=16 \mathrm{~m}\right) \\
\text { Alt. } 2\left(S I_{20}=16 \mathrm{~m}\right) \\
\text { Alt. } 3\left(S I_{20}=16 \mathrm{~m}\right)\end{array}$ & $\begin{array}{l}5319.7 \\
6268.0 \\
6915.4\end{array}$ & $\begin{array}{l}1881.4 \\
2344.4 \\
2857.4\end{array}$ & $\begin{array}{l}2633.2 \\
3197.1 \\
3731.3\end{array}$ & $\begin{array}{l}3385.1 \\
4049.8 \\
4605.1\end{array}$ & $\begin{array}{l}1122.3 \\
1497.1 \\
1954.7\end{array}$ & $\begin{array}{l}0.0628 \\
0.0668 \\
0.0733\end{array}$ \\
\hline $\begin{array}{l}\text { Alt. } 1\left(S I_{20}=13 \mathrm{~m}\right) \\
\text { Alt. } 2\left(S I_{20}=13 \mathrm{~m}\right) \\
\text { Alt. } 3\left(S I_{20}=13 \mathrm{~m}\right)\end{array}$ & $\begin{array}{l}1081.1 \\
3168.8 \\
4685.7\end{array}$ & $\begin{array}{c}-292.6 \\
744.6 \\
1726.8\end{array}$ & $\begin{array}{c}-30.6 \\
1277.3 \\
2344.7\end{array}$ & $\begin{array}{c}231.4 \\
1809.9 \\
2962.7\end{array}$ & $\begin{array}{c}-647.5 \\
238.9 \\
1040.4\end{array}$ & $\begin{array}{l}0.0396 \\
0.0533 \\
0.0643\end{array}$ \\
\hline $\begin{array}{l}\text { Natural regeneration: } \\
\text { Alt. } 1\left(S_{20}=16 \mathrm{~m}\right) \\
\text { Alt. } 2\left(S I_{20}=16 \mathrm{~m}\right) \\
\text { Alt. } 3\left(S I_{20}=16 \mathrm{~m}\right)\end{array}$ & $\begin{array}{l}6953.8 \\
7482.1 \\
7944.4\end{array}$ & $\begin{array}{l}3298.6 \\
3419.6 \\
3773.2\end{array}$ & $\begin{array}{l}4050.5 \\
4272.2 \\
4646.9\end{array}$ & $\begin{array}{l}4802.4 \\
5125.0 \\
5520.8\end{array}$ & $\begin{array}{l}2423.1 \\
2501.9 \\
2814.1\end{array}$ & $\begin{array}{l}0.0987 \\
0.0975 \\
0.1051\end{array}$ \\
\hline $\begin{array}{l}\text { Alt. } 1\left(S I_{20}=13 \mathrm{~m}\right) \\
\text { Alt. } 2\left(S I_{20}=13 \mathrm{~m}\right) \\
\text { Alt. } 3\left(S I_{20}=13 \mathrm{~m}\right)\end{array}$ & $\begin{array}{l}2714.9 \\
4382.8 \\
5714.8\end{array}$ & $\begin{array}{l}1124.6 \\
1819.9 \\
2642.5\end{array}$ & $\begin{array}{l}1386.7 \\
2352.5 \\
3260.4\end{array}$ & $\begin{array}{l}1648.7 \\
2885.2 \\
3878.4\end{array}$ & $\begin{array}{c}653.2 \\
1243.8 \\
1899.7\end{array}$ & $\begin{array}{l}0.0674 \\
0.0767 \\
0.0898\end{array}$ \\
\hline
\end{tabular}

An essential pre-requisite for developing a good plan combining stand level results and forest-wide constraints would be to use the growth projection system applied in the present paper for simulating various acceptable management regimes for each compartment of a given forest property [9]. In this context, the third alternative could serve as reference concept to ensure that each management regime is goal-oriented from a silvicultural point of view. Some of the harvesting schedules, which result from the specification of alternative management regimes would satisfy the forest wide constraints and some would not. Consequently, the forest-level planning problem involved is to identify the most desired forestwide schedule and one of the methods which have been used with good success, and apply the algorithm presented by Hoganson and Rose [13].

The analysis carried out in the present paper focused only on economic criteria. However, multiple-use aspects such as protection, recreation, and nature conservation are of increasing importance in Galicia. The third alternative shows clear advantages in this context. The relatively low stand density improves the possibility for recreation, favours the coexistence of deciduous tree species, and reduces the risk of forest fire. The evaluation of silvicultural alternatives for such multi-objective situations could be carried out in the future using innovative methods, for example Saaty's analytical hierarchy process approach [26].

Another important task for future research in Galicia would be to simulate and document the interaction of sil- vicultural treatments with wood and fibre quality aspects like proportion of juvenile wood at harvest $[5,7,14]$, which will become one of the major concerns in the forest products industry throughout the world.

Acknowledgements: The research reported in this paper was supported by the Department of Agriculture, Forest Service, Autonomous Government of Galicia (Spain). This work is dedicated to the memory of Víctor Jiménez, who as Forest Vice-Director promoted decidedly the research. We thank Klaus von Gadow, Guillermo Vega, and the anonymous reviewers for their comments and collaboration.

\section{REFERENCES}

[1] Álvarez J.G., Análisis y caracterización de las distribuciones diamétricas de Pinus pinaster Ait en Galicia. PhD Thesis, Universidad Politécnica de Madrid, ETS Ingenieros de Montes, 1997.

[2] Álvarez J.G., Rodríguez Soalleiro R., Vega Alonso G., Desarrollo de un modelo dinámico de crecimiento para masas de Pinus pinaster Ait en Galicia, Investigación Agraria, Sist. Rec. For. 8 (1999) 319-334.

[3] Calvet P., Lemoine B., Peyron J.L., Discount rate and silvicultural management of forest stands: an example of maritime pine in France, Can. J. For. Res. 27 (1997) 1268-1275.

[4] Clutter J.L., Fortson J.C., Pienaar L.V., Brister G.H., Bailey R.L. Timber management - a quantitative approach, John Wiley \& Sons, New York, 1983. 
[5] Dumail J.F., Castera P., Transverseshrinkage in maritime pine juvenile wood, Wood science and Technology 31 (1997) 251-264.

[6] Echeverría I., De Pedro S., El Pinus pinaster en Pontevedra: su productividad normal y aplicación a la celulosa industrial, Boletín IFIE 38, Madrid, 1948.

[7] Fernández Golfín J.I., Reflexiones sobre las interacciones entre la selvicultura y la calidad de la madera (coníferas), Montes 47 (1997) 49-51.

[8] Fernández Tomás G., Aspectos económicos de la Ordenación de Montes, in: Madrigal A. (Ed.), Ordenación de montes arbolados, ICONA, Madrid, 1994.

[9] Gadow K. von, Dynamic forest resource planning, in: Moiseev N.A., von Gadow K., Krott M. (Eds.), Planning and decision making for forest management in the market economy, 3. IUFRO International Conference at Pushkino, Russia, September 1996, 25-20, 77-87.

[10] Gadow K. von, Hui G.Y., Modelling forest development, Kluver Academic Publishers, Amsterdam, 1999.

[11] García O., Growth modelling - A (re)view, N. Z. For. 33 (1988) 14-17.

[12] García, O., The state-space approach in growth modelling, Can. J. For. Res. 24 (1994) 1894-1903.

[13] Hoganson H.M., Rose D.W., A simulation approach for optimal timber management scheduling, For. Sci. 30 (1984) 200-238.

[14] Keller R., Characteristics of Pinus pinaster wood: their variability and heritability, Ann. Sci. For. 30 (1973) 31-62.

[15] Madrigal A., Toval G., Tablas de producción, cubicación y tarifas de Pinus radiata D. Don en las provincias vascongadas. Ministerio de Agricultura, Dirección General de la Producción Agraria, Madrid, 1975.

[16] Madrigal A., Martínez Millán J., Alternativas selvícolas del Pinus pinaster Ait. en Galicia. Premio ENCE de Investigación Forestal, 1992 (unpublished).

[17] Miina J., Optimizing thinning and rotation in a stand of Pinus sylvestris on a drained peatland site, Scand. J. For. Res. 11 (1996) 182-192.
[18] Miina J., Preparation of stand management models using simulation and optimization, in: Pukkala T., Eerikainen K. (Eds.), Tree seedling production and management of plantation forests. Univ. of Joensuu, Research Note 68, 1998, pp. 153-161.

[19] Peyron J.-L., Terreaux J.-P., Calvet P., Guo B., Principaux critères économiques de gestion des forêts : analyse critique et comparative, Ann. For. Sci. 55 (1998) 523-551.

[20] Platinga A.J., The optimal timber rotation: an option value approach, For. Sci. 44 (1998) 192-202.

[21] Porté A., Bosc A., Champion I., Loustau D., Estimating the foliage area of Maritime pine (Pinus pinaster Ait.) branches and crowns with application to modelling the foliage area distribution in the crown, Ann. For. Sci. 57 (2000) 73-86.

[22] Rodríguez Soalleiro R., Álvarez González J.G., Vega Alonso G., Revisión de las curvas de calidad de estación de Pinus pinaster en Galicia. Ponencias y Comunicaciones del Congreso Forestal Español, Lourizán 1993. SECF, Xunta de Galicia, Tomo II, pp. 587-592.

[23] Rodríguez Soalleiro R., Crecimiento y producción de masas regulares de Pinus pinaster Ait. en Galicia. Alternativas selvícolas posibles. PhD Thesis, Universidad Politécnica de Madrid, ETS de Ingenieros de Montes, 1995.

[24] Ruíz Dana J.M., Estudio de los coeficientes mórficos del Pinus pinaster en Galicia, Montes 114 (1963) 487-496.

[25] Schröder J., Álvarez J.G., Developing a generalized diameter- height model for maritime pine in Northwest Spain. FAIR-BM-956863, final scientific report. Centro de Investigaciones Forestales de Lourizán, Pontevedra, 1998.

[26] Steinmeyer A., Gadow K. von, Saaty's AHP dargestellt am Beispiel der Waldbiotopkartierung. Centralblatt f. d. ges. Forstwesen 112 (1994) 53-65.

[27] Torres J.M., Brodie J.D., Demonstration of benefits from an optimization approach to the economic analysis of natural pine stands in Central Mexico, For. Ecol. Man. 36 (1990) 267-278.

To access this journal online: www.edpsciences.org 